University of Nebraska - Lincoln

DigitalCommons@University of Nebraska - Lincoln

3-2-2007

\title{
Vegetation water content during SMEX04 from ground data and Landsat 5 Thematic Mapper imagery
}

\author{
M. Tugrul Yilmaz \\ Hydrology and Remote Sensing Laboratory, Beltsville, Maryland \\ E. Raymond Hunt, Jr. \\ Hydrology and Remote Sensing Laboratory, Beltsville, Maryland, Raymond.Hunt@ars.usda.gov \\ Lyssa D. Goins \\ University of Arizona \\ Susan L. Ustin \\ University of California - Davis \\ Vern C. Vanderbilt \\ NASA Ames Research Center \\ See next page for additional authors
}

Follow this and additional works at: https://digitalcommons.unl.edu/nasapub

Part of the Physical Sciences and Mathematics Commons

Yilmaz, M. Tugrul; Hunt, Jr., E. Raymond; Goins, Lyssa D.; Ustin, Susan L.; Vanderbilt, Vern C.; and Jackson, Thomas J., "Vegetation water content during SMEX04 from ground data and Landsat 5 Thematic Mapper imagery" (2007). NASA Publications. 27.

https://digitalcommons.unl.edu/nasapub/27

This Article is brought to you for free and open access by the National Aeronautics and Space Administration at DigitalCommons@University of Nebraska - Lincoln. It has been accepted for inclusion in NASA Publications by an authorized administrator of DigitalCommons@University of Nebraska - Lincoln. 
Authors

M. Tugrul Yilmaz; E. Raymond Hunt, Jr.; Lyssa D. Goins; Susan L. Ustin; Vern C. Vanderbilt; and Thomas J. Jackson 


\title{
Vegetation water content during SMEX04 from ground data and Landsat 5 Thematic Mapper imagery
}

\author{
M. Tugrul Yilmaz ${ }^{\text {a }}$, E. Raymond Hunt Jr. ${ }^{\text {a,* }}$, Lyssa D. Goins ${ }^{\text {b }}$, Susan L. Ustin ${ }^{\text {c }}$, \\ Vern C. Vanderbilt ${ }^{\mathrm{d}}$, Thomas J. Jackson ${ }^{\mathrm{a}}$ \\ ${ }^{a}$ USDA Agricultural Research Service, Hydrology and Remote Sensing Laboratory, Beltsville MD, USA \\ ${ }^{\mathrm{b}}$ Soil, Water and Environmental Sciences, University of Arizona, Tucson AZ, USA \\ ${ }^{\mathrm{c}}$ Department of Land Air and Water Resources, University of California, Davis CA, USA \\ d NASA Ames Research Center, Moffett Field CA, USA
}

Received 7 April 2006; received in revised form 5 February 2007; accepted 2 March 2007

\begin{abstract}
Vegetation water content is an important parameter for retrieval of soil moisture from microwave data and for other remote sensing applications. Because liquid water absorbs in the shortwave infrared, the normalized difference infrared index (NDII), calculated from Landsat 5 Thematic Mapper band $4(0.76-0.90 \mu \mathrm{m}$ wavelength) and band 5 (1.55-1.65 $\mu \mathrm{m}$ wavelength), can be used to determine canopy equivalent water thickness (EWT), which is defined as the water volume per leaf area times the leaf area index (LAI). Alternatively, average canopy EWT can be determined using a landcover classification, because different vegetation types have different average LAI at the peak of the growing season. The primary contribution of this study for the Soil Moisture Experiment 2004 was to sample vegetation for the Arizona and Sonora study areas. Vegetation was sampled to achieve a range of canopy EWT; LAI was measured using a plant canopy analyzer and digital hemispherical (fisheye) photographs. NDII was linearly related to measured canopy EWT with an $R^{2}$ of 0.601 . Landcover of the Arizona, USA, and Sonora, Mexico, study areas were classified with an overall accuracy of $70 \%$ using a rule-based decision tree using three dates of Landsat 5 Thematic Mapper imagery and digital elevation data. There was a large range of NDII per landcover class at the peak of the growing season, indicating that canopy EWT should be estimated directly using NDII or other shortwave-infrared vegetation indices. However, landcover classifications will still be necessary to obtain total vegetation water content from canopy EWT and other data, because considerable liquid water is contained in the nonfoliar components of vegetation.
\end{abstract}

Published by Elsevier Inc.

Keywords: Decision tree classification; Equivalent water thickness; Leaf area index; Normalized difference infrared index; Soil Moisture Experiment 2004

\section{Introduction}

As part of the North American Monsoon Experiment, the Soil Moisture Experiment 2004 (SMEX04) was conducted in Arizona, USA, and Sonora, Mexico, to test soil moisture retrievals as a function of topography (Cosh et al., 2008-this issue; Jackson, 2004; Vivoni et al., 2008-this issue). One of the parameters for retrieval of soil moisture from active and passive microwave remote sensing is the vegetation water content

\footnotetext{
* Corresponding author. USDA ARS HRSL, Building 007, Room 104, BARC-West, 10300 Baltimore Avenue, Beltsville, MD 20705-2350, USA. Tel.: +1 301504 5278; fax: +1 3015048931 .

E-mail address: Raymond.Hunt@ars.usda.gov (E.R. Hunt).
}

(Jackson et al., 2004), which is the total mass of liquid water in stems and foliage per ground area $\left(\mathrm{kg} \mathrm{m}^{-2}\right)$. If vegetation water content can be estimated independently from other satellite data, then the retrievals of soil moisture would be more accurate. Furthermore, vegetation water content may be useful in detecting wildfire potential (Chuvieco et al., 2002; Dennison et al., 2005; Maki et al., 2004; Zarco-Tejada et al., 2003).

Liquid water strongly absorbs incident solar radiation in the short-wave infrared wavelength region (Palmer \& Williams, 1974; Tucker, 1980), thus reflectance spectra of leaves and canopies may be used to estimate the volume of liquid water per leaf area or ground area, respectively, which is termed the equivalent water thickness (EWT, mm). Many satellite sensors have bands in the shortwave infrared wavelength region such as 
Landsat 5 Thematic Mapper and the MODerate resolution Imaging Spectrometer (MODIS). Thus, determination of canopy EWT is a step towards the remote sensing of total vegetation water content.

There have been many studies relating EWT and shortwave infrared reflectances at the leaf level (Baret \& Fourty, 1997; Danson et al., 1992; Datt, 1999; Hunt \& Rock, 1989; Sims \& Gamon, 2003; Stimson et al., 2005; and others), but fewer at the canopy level with airborne or satellite sensors (Ceccato et al., 2002; Chen et al., 2005; Davidson et al., 2006; Hunt, 1991; Jackson et al., 2004; Zarco-Tejada et al., 2003). Much of the effort has been to develop and test multispectral indices for estimation of EWT or vegetation water content (Ceccato et al., 2002; Fensholt \& Sandholt, 2003; Gao, 1996; Hardisky et al., 1983; Hunt \& Rock, 1989; Peñuelas et al., 1997; Tucker, 1980).

Leaf area index (LAI) is a major variable affecting canopy EWT (Anderson et al., 2004; Hunt, 1991; Roberts et al., 1998, 2004) so vegetation types with higher LAI (e.g. forests) will have higher canopy EWT than areas with lower LAI (e.g. shrublands). Maximum LAI is determined by vegetation type (Woodward, 1987), and generally vegetation types with a higher maximum LAI will also have higher average LAI. For many purposes such as ecosystem modeling, parameter averages can be selected for each vegetation type and a landcover classification is used to distribute the parameter averages regionally or globally (Muchoney \& Strahler, 2002; Running et al., 1995). To determine total vegetation water content including water in stems, landcover information will be necessary. It is therefore reasonable to ask if average values for canopy EWT can be assigned by vegetation type, so estimating canopy EWT from multispectral indices would not be necessary when the vegetation is at peak LAI for the growing season.

We hypothesize that remote sensing of canopy EWT from multispectral indices provides more information than vegetation type from a landcover classification. Landsat 5 Thematic Mapper (TM) imagery were acquired for several dates during SMEX04 and the TM sensor has an important shortwave infrared band (TM band $5,1.55-1.75 \mu \mathrm{m}$ wavelength). We sampled LAI and leaf EWT for plots of different vegetation types during SMEX04, and used these data to compare canopy EWT from multispectral indices and vegetation type.

\section{Field methods}

\subsection{SMEX04 study areas}

There were two study areas selected for SMEX04, one in Arizona, USA, and one in Sonora, Mexico (Jackson, 2004). The Arizona study area $\left(50 \mathrm{~km}\right.$ by $75 \mathrm{~km}$; between $31^{\circ} 25^{\prime} \mathrm{N}$ and $32^{\circ} 7^{\prime} \mathrm{N}$, and $109^{\circ} 43^{\prime} \mathrm{W}$ and $110^{\circ} 14^{\prime} \mathrm{W}$ ) was centered about the Walnut Gulch Experimental Watershed surrounding Tombstone, Arizona. The study area includes the San Pedro River and ranges in elevation from $1093 \mathrm{~m}$ to $2285 \mathrm{~m}$, with an average elevation of $1389 \mathrm{~m}$. Mean annual temperature at Tombstone, Arizona (1380 m elevation) is $17.7{ }^{\circ} \mathrm{C}$ and the mean annual precipitation is $350 \mathrm{~mm}$, which about $67 \%$ falls during the summer monsoon.
The Sonora study area $\left(50 \mathrm{~km}\right.$ by $90 \mathrm{~km}$; between $29^{\circ} 41^{\prime} \mathrm{N}$ and $30^{\circ} 30^{\prime} \mathrm{N}$, and $110^{\circ} 14^{\prime} \mathrm{W}$ and $110^{\circ} 46^{\prime} \mathrm{W}$ ) is centered on the mountain highlands between the Sonora River and the San Miguel River. The elevations range from $525 \mathrm{~m}$ to $2230 \mathrm{~m}$, with an average elevation of $1033 \mathrm{~m}$. Mean annual temperature at Opodepe, Sonora (690 m elevation) is $20.8{ }^{\circ} \mathrm{C}$ and the mean annual precipitation is $477 \mathrm{~mm}$, which about $67 \%$ falls during the summer monsoon.

\subsection{SMEX04 site selection and measurement}

The main objectives of SMEX04 were to intensively sample soil moisture over the Walnut Gulch Experimental Watershed and regionally sample soil moisture over the Arizona and Sonora study areas (Jackson, 2004). Because there were fewer people sampling the vegetation, we could not achieve the same temporal or spatial coverage as occurred for sampling soil moisture. Hence, the objectives for SMEX04 were to sample the range of plant communities present, and to use sensors, such as Landsat 5 TM and MODIS to extrapolate vegetation water content spatially and temporally. The sampling protocols evolved over SMEX04; the key measurements for each site included ground cover, LAI, and leaf EWT.

Plot locations and vegetation types were established for the Arizona study area in June and July, 2004 before the start of the SMEX04 experiment. Because the goal was to sample a range of vegetation types, most of the plots were not co-located with soil moisture sites (Cosh et al., 2008-this issue). The first four vegetation plots selected were the four eddy flux sites (Table 1). Many vegetation plots were located in the riparian corridors of the San Pedro River and its tributaries, at higher elevations, or in irrigated agricultural fields, where LAI was expected to be higher than the desert shrubland or grassland communities. Initially, at least two locations were selected for each vegetation type; however, riparian woodland and riparian mesquite communities were only measured once.

Plot locations in Sonora were co-located with the SMEX04 soil moisture sites, along roads in the mountains, in the northern and southern portions of the Sonora study area (Table 1). Six of the plots were co-located along an elevational transect (Vivoni et al., 2008-this issue).

At each location, square plots were established with 40-m sides. The corners of the plots were geolocated with either a Garmin (Olathe, Kansas, U.S.A.) eTrex Legend global positioning system enabled with the wide-area augmentation system (4-8 $\mathrm{m}$ accuracy) or a Trimble (Sunnyvale, California, U.S.A) Pro XRS global positioning system (3-5 m accuracy). Starting $5 \mathrm{~m}$ from one edge, a series of 7 transects $5 \mathrm{~m}$ apart were positioned. LAI and cover were measured along these transects.

Cover was measured using the line-intercept technique (Mueller-Dombois \& Ellenberg, 1974). The cover category was determined at the point of the foot at every 1 to $1.5 \mathrm{~m}$ ( 2 steps) along each transect; categories were: live vegetation (green) either by species (when identified) or vegetation type, litter (stem or leaf), and bare (soil or rock). Percent cover was determined from the total in each category divided by the total number of points sampled in the plot. 
Table 1

Vegetation plot classification, date sampled, elevation, location, and cover fractions during SMEX04

\begin{tabular}{|c|c|c|c|c|c|c|c|}
\hline \multirow[t]{2}{*}{ Site name (class) } & \multirow[t]{2}{*}{ Date } & \multirow{2}{*}{$\begin{array}{l}\text { Elevation } \\
(\mathrm{m})\end{array}$} & \multicolumn{2}{|c|}{ Coordinates $\left(^{\circ}\right)$} & \multicolumn{3}{|c|}{ Cover (fraction) } \\
\hline & & & Lat $\mathrm{N}$ & Lon W & Green & Litter & Bare \\
\hline AZ Maize (agriculture) & 29Jul & 1301 & 31.9772 & 109.8582 & 1.00 & 0.00 & 0.00 \\
\hline AZ Chili (agriculture) & 29Jul & 1304 & 31.9718 & 109.8582 & 0.73 & 0.00 & 0.27 \\
\hline AZ Lewis Springs (sacaton) ${ }^{a}$ & 29Jul & 1233 & 31.5606 & 110.1398 & - & - & - \\
\hline AZ Lucky Hills (shrub) ${ }^{a}$ & 30Jul & 1366 & 31.7434 & 110.0523 & 0.53 & 0.00 & 0.47 \\
\hline AZ Kendell (grass) ${ }^{\mathrm{a}}$ & 30Jul & 1533 & 31.7371 & 109.9419 & 0.57 & 0.02 & 0.40 \\
\hline AZ Lewis Springs (rip. mesquite) ${ }^{a}$ & 30Jul & 1236 & 31.5651 & 110.1361 & 0.80 & 0.08 & 0.11 \\
\hline AZ RG13 (shrub) ${ }^{\mathrm{b}}$ & 31Jul & 1328 & 31.7246 & 110.0909 & 0.53 & 0.00 & 0.47 \\
\hline AZ Kendell (whitethorn shrub) & 31Jul & 1504 & 31.7376 & 109.9558 & 0.69 & 0.11 & 0.20 \\
\hline AZ Stronghold (grass) & 2Aug & 1540 & 31.8547 & 110.0085 & 0.56 & 0.24 & 0.20 \\
\hline AZ Stronghold South (oak) & 2Aug & 1533 & 31.7369 & 109.9418 & 0.75 & 0.24 & 0.00 \\
\hline AZ Stronghold North (oak) & 2Aug & 1514 & 31.8635 & 110.0165 & 0.80 & 0.17 & 0.03 \\
\hline AZ San Pedro (rabbitbrush shrub) & 3Aug & 1237 & 31.5372 & 110.1336 & 0.52 & 0.22 & 0.26 \\
\hline AZ San Pedro (riparian wood) & $3 \mathrm{Aug}$ & 1235 & 31.5379 & 110.1335 & 0.98 & 0.00 & 0.02 \\
\hline AZ San Pedro (sacaton) & 3Aug & 1231 & 31.5565 & 110.1427 & - & - & - \\
\hline AZ RG57 (beargrass shrub) ${ }^{b}$ & 7Aug & 1463 & 31.7283 & 109.9859 & 0.49 & 0.05 & 0.46 \\
\hline SO 135 (mesquiteshrub) $^{\mathrm{b}}$ & 6Aug & 1064 & 30.2550 & 110.5149 & 0.64 & 0.17 & 0.20 \\
\hline SO $134\left(\right.$ oak) ${ }^{\text {b }}$ & 6Aug & 1216 & 30.2199 & 110.4616 & 0.56 & 0.09 & 0.35 \\
\hline SO TID1 (oak) ${ }^{\mathrm{c}}$ & 6Aug & 1279 & 29.9728 & 110.4695 & 0.66 & 0.19 & 0.16 \\
\hline SO TID2 (oak) ${ }^{\mathrm{c}}$ & 6Aug & 1279 & 29.9709 & 110.4707 & 0.86 & 0.04 & 0.10 \\
\hline SO TID4 (oak) ${ }^{\mathrm{c}}$ & 7Aug & 1258 & 29.9684 & 110.4722 & 0.74 & 0.17 & 0.09 \\
\hline SO TID5 (oak) ${ }^{\mathrm{c}}$ & 7Aug & 1147 & 29.9716 & 110.4776 & 0.81 & 0.00 & 0.19 \\
\hline 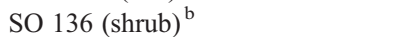 & $7 \mathrm{Aug}$ & 988 & 30.3127 & 110.6736 & 0.72 & 0.03 & 0.25 \\
\hline SO 143 (mesquiteshrub) $^{b}$ & 7Aug & 971 & 30.3416 & 110.5561 & 0.61 & 0.09 & 0.30 \\
\hline SO TID7 (subtropical) ${ }^{\mathrm{c}}$ & 8Aug & 900 & 29.9639 & 110.5183 & 0.24 & 0.00 & 0.76 \\
\hline SO TID13 (subtropical) ${ }^{\mathrm{c}}$ & 8Aug & 900 & 29.9623 & 110.5209 & 0.70 & 0.00 & 0.30 \\
\hline
\end{tabular}

\footnotetext{
a Flux site.

b SMEX04 raingauge and soil moisture sampling site.

c TID, Elevational Transect ID Number.
}

\subsection{Leaf area index}

LAI ( $\mathrm{m}^{2}$ leaf area per $\mathrm{m}^{2}$ ground area) was estimated during the SMEX04 field campaign using two different methods: the LI-COR, Inc. (Lincoln, Nebraska, USA) LAI-2000 Plant Canopy Analyzer, and digital hemispherical (fisheye) photographs. The LAI-2000 was used for low-statured vegetation (shrublands and grasslands) in the Arizona study area, whereas hemispherical photographs were obtained for almost all plots. The hemispherical photographs and LAI-2000 measurements were generally obtained every $5 \mathrm{~m}$ along each of the seven plot transects, starting $5 \mathrm{~m}$ from the plot edge. When possible, the LAI measurements with both techniques were obtained under diffuse skylight conditions (Wells \& Norman, 1991). However, for some plots (occurring mostly in the Sonora study area), LAI could only be measured under direct sunlight; for these plots, LAI was increased 10\% (John Norman, personal communication; Anderson et al., 2004).

For the LAI-2000, at each transect location, a single LAI value was obtained from an above-canopy reading, followed by 4 sub-canopy readings, where each of the four readings were shifted about $0.5 \mathrm{~m}$ in a diamond-shaped pattern. The lens of the LAI-2000 was partially covered to allow a $270^{\circ}$ field of view in front of the user.

The hemispherical photographs were acquired using a Nikon Coolpix 5400 digital camera with an $8-\mathrm{mm}$ focal-length lens. A tripod, compass and bubble level were used to mount the camera horizontally about $25 \mathrm{~mm}$ off the ground, with the top of the

camera always facing north. The resulting digital photographs were analyzed with HemiView Canopy Analysis Software, Version 2.1 SR1 (Delta-T Devices, Ltd., Cambridge, U.K.).

After analyzing the LAI-2000 and hemispherical photographs for the same plots in the Arizona study area, it was found that LAI from the hemispherical photographs were significantly less than LAI from the LAI-2000. A possible reason for this discrepancy is that we used the automatic exposure time for the digital camera (Zhang et al., 2005). Therefore, we obtained more concurrent measurements of LAI with both the LAI-2000 and hemispherical photographs at 71 sites (pastures, meadows and woodlands) at the Beltsville Agricultural Research Center, Beltsville, Maryland, USA. For woodland sites, two LAI-2000 were used, one for the clear sky reading and one for underneath the canopy. A strong correlation was found $\left(r^{2}=0.94\right)$ between the two methods (Fig. 1). The regression equation was used to adjust the LAI calculated from the hemispherical photographs to the expected value from the LAI-2000 for all plots during SMEX04. The mean of all measurements (with both techniques when LAI-2000 data were acquired) were used for the plot average LAI.

\subsection{Leaf and canopy EWT}

At most plots, several leaf samples of the dominant vegetation were clipped, sealed in small plastic bags, and placed into a cool, dark container to avoid water loss as much as possible. Upon return to an air-conditioned room, a sub-sample of the 


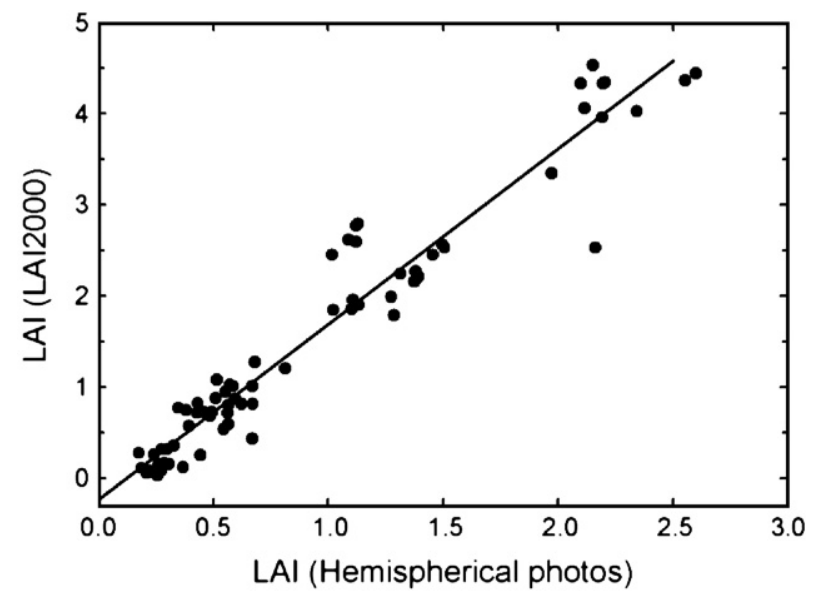

Fig. 1. Calibration of Leaf Area Index $\left(\mathrm{LAI}, \mathrm{m}^{2} \mathrm{~m}^{-2}\right.$ ) from digital hemispherical (fisheye) photographs with the LICOR LAI-2000 Plant Canopy Analyzer. LAI of 71 plots at 5 sites at the USDA Beltsville Agricultural Research Center were measured to extend the range for the calibration equation. The equation is $y=1.9175 x-0.2121$, with an $R^{2}$ of 0.935 .

leaves were removed, weighed, and photographed with a 4megapixel digital camera. In each photograph, reference squares of $12.7 \mathrm{~mm}$ by $12.7 \mathrm{~mm}, 25.4 \mathrm{~mm}$ by $25.4 \mathrm{~mm}$, and $63.5 \mathrm{~mm}$ by $63.5 \mathrm{~mm}$, were placed in the photographs for scale. The digital photographs were classified for green vegetation using minimum distance supervised classification. Leaf area was then calculated by counting the number of green pixels and multiplying by the scale determined from the reference squares. Leaf samples were weighed at $60^{\circ} \mathrm{C}$ in a drying oven to obtain dry weight. Leaf EWT (EWT leaf $)$ was calculated:

$\mathrm{EWT}_{\text {leaf }}=(\mathrm{FWT}-\mathrm{DWT}) / A_{\text {leaf }}$

where FWT is the sample fresh weight (kg), DWT is the sample dry weight $(\mathrm{kg})$, and $A_{\text {leaf }}$ is the sample leaf area $\left(\mathrm{m}^{2}\right)$. Dividing
$\mathrm{EWT}_{\text {leaf }}$ by the density of water $\left(1000 \mathrm{~kg} \mathrm{~m}^{-3}\right)$, the units of $\mathrm{EWT}_{\text {leaf }}$ are converted from $\mathrm{kg} \mathrm{m}^{-2}$ to meters. Canopy EWT $\left(\mathrm{EWT}_{\text {canopy }}\right)$ was defined:

$\mathrm{EWT}_{\text {canopy }}=\mathrm{EWT}_{\text {leaf }} \cdot \mathrm{LAI}$

which is the depth of foliar liquid water per unit area of ground (Hunt, 1991).

\section{Landsat 5 Thematic Mapper}

\subsection{Acquisition and georeferencing}

As part of SMEX04, Landsat 5 TM scenes (level 1G) were acquired on three dates (11 June 2004, 29 July 2004, and 30 August 2004), one for the Arizona study area (Path 35/Row 38) and one for the Sonora study area (Path 35/Row 39). The two scenes were mosaicked into one image for each date (Fig. 2). There was little cloud cover: $<1 \%$ on 11 June, $<5 \%$ on 29 July, and $<1 \%$ on 30 August. The images were then registered using the Environment for Visualizing Images (ENVI) version 4.1 (Research Systems, Inc., Boulder CO, USA). USGS Digital Orthophoto Quads were used to obtain 10 ground control points for the Arizona study area. The residual mean square error was $<20 \mathrm{~m}$ for each image (Fig. 2).

\subsection{Atmospheric correction}

In order to get top-of-the-canopy reflectances, the digital numbers for Landsat bands $1-5$ and 7 were converted first into radiances:

$L=\left[\left(L_{\max }-L_{\min }\right) \cdot Q_{\text {cal }} / Q_{\text {cal } \max }\right]+L_{\text {min }}$

where, $L$ is the spectral radiance at the sensor's aperture $\left(\mathrm{W} \mathrm{m}^{-2}\right.$ $\left.\mathrm{sr}^{-1} \mu \mathrm{m}^{-1}\right), Q_{\text {cal }}$ is the quantized calibrated pixel value in digital
A. June

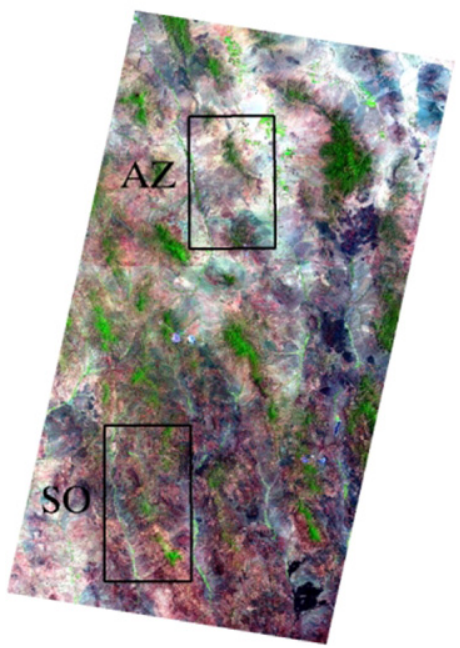

B. July

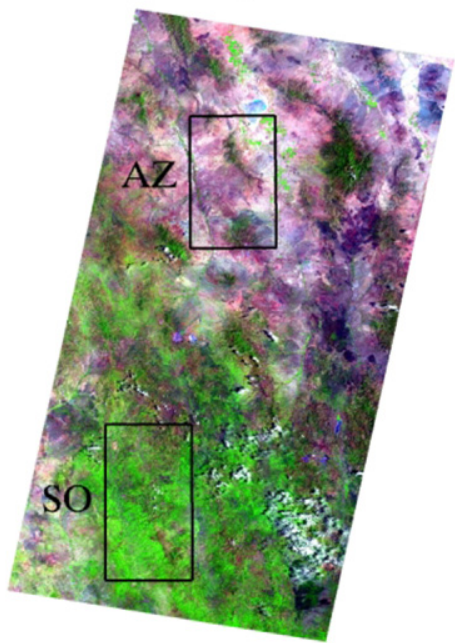

C. August

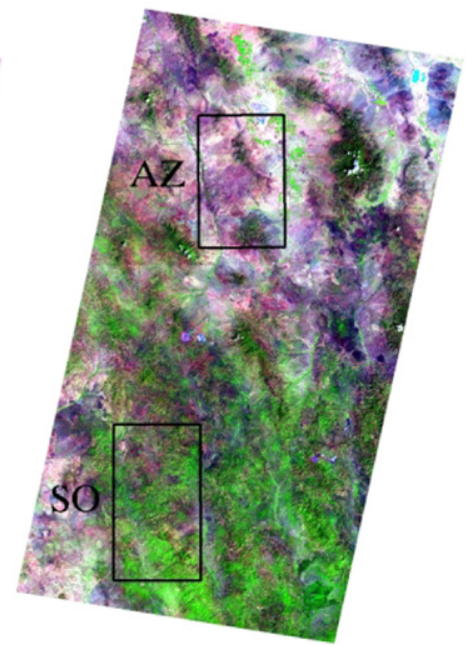

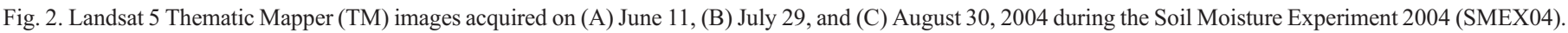

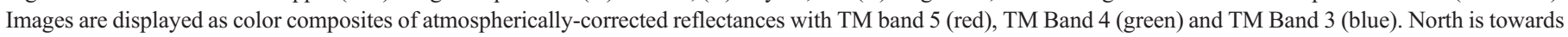
the top of the figure. The boxes represent the 75-km-by-50-km Arizona, USA study area (AZ) and the 90-km-by-50-km Sonora, Mexico study area (SO). 
number (DN), $Q_{\text {cal } \min }$ is the minimum quantized calibrated pixel value $(\mathrm{DN}=0), Q_{\text {cal }} \max$ is the maximum quantized calibrated pixel value $(\mathrm{DN}=255), L_{\min }$ is the spectral radiance (W m ${ }^{-2} \mathrm{sr}^{-1} \mu \mathrm{m}^{-1}$ ) scaled to $Q_{\text {cal min }}$, and $L_{\text {max }}$ is the spectral radiance $\left(\mathrm{W} \mathrm{m}^{-2} \mathrm{sr}^{-1} \mu \mathrm{m}^{-1}\right)$ scaled to $Q_{\text {cal max }}$ (Chander \& Markham, 2003). The values of $L_{\min }, L_{\max }$ and $Q_{\text {cal max }}$ are taken from Landsat-5 TM post-calibration of the dynamic ranges for US Processes National Landsat Archive Production System (Chander \& Markham, 2003).

The atmospheric correction for all channels was conducted using the MODerate resolution atmospheric TRANsmission (MODTRAN) model (Adler-Golden et al., 1999). As input data for MODTRAN, sun photometer data were obtained through the NASA Goddard Space Flight Center AERONET network (http://aeronet.gsfc.nasa.gov), ozone content data were obtained from Environment Canada (http://woudc.ec.gc.ca/cgi-bin/select Map/), radiosonde data were obtained from National Oceanic and Atmospheric Administration (http://raob.fsl.noaa.gov/), and meteorological data were obtained from nearby weather stations.

If the area surrounding a target is assumed to be similar to the target and the target is a Lambertian surface, the reflectance at the target is expressed:

$\rho=\pi\left(L-L_{\mathrm{p}}\right) /\left[T\left(E_{\mathrm{dir}}+E_{\mathrm{diff}}\right)+\pi S\left(L-L_{\mathrm{p}}\right)\right]$

where: $L_{\mathrm{p}}$ is the atmospheric path radiance $\left(\mathrm{W} \mathrm{m}^{-2} \mathrm{sr}^{-1} \mu \mathrm{m}^{-1}\right.$ ), $E_{\text {dir }}$ is the direct irradiance at the surface ( $\left.\mathrm{W} \mathrm{m}^{-2}\right), E_{\text {diff }}$ is the diffuse irradiance at the surface $\left(\mathrm{W} \mathrm{m}^{-2}\right), S$ is the reflectance of the atmosphere, and $T$ is the total diffuse transmittance from the ground to the top of the atmosphere in the view direction of the satellite (Adler-Golden et al., 1999; Vermote et al., 1997; Vermote \& Vermeulen, 1999). MODTRAN was used to estimate the parameters in Eq. (4), so that $\rho$ for Landsat bands $1-5$ and 7 were calculated.

\subsection{Vegetation indices}

Canopy EWT is usually remotely sensed using various vegetation indices. The most common index using in remote sensing is the normalized difference vegetation index (NDVI; Rouse et al., 1974):

$\mathrm{NDVI}=\left(\rho_{0.85}-\rho_{0.66}\right) /\left(\rho_{0.85}+\rho_{0.66}\right)$

where $\rho_{0.85}$ is the reflectance of a near-infrared band and $\rho_{0.66}$ is the reflectance of a red band at about $0.85 \mu \mathrm{m}$ and $0.66 \mu \mathrm{m}$ wavelength, respectively. This index is correlated to LAI (Baret \& Guyot, 1991; Franklin et al., 1997; Peterson et al., 1987; Tucker, 1979). This index also differentiates between green vegetation and soil background, and is also useful for landcover classification. Because a major variable affecting the canopy EWT is LAI (Hunt, 1991; Roberts et al., 1998, 2004), NDVI should be correlated to canopy EWT. Hardisky et al. (1983) proposed the normalized difference infrared index (NDII) as correlated to plant moisture content:

$\mathrm{NDII}=\left(\rho_{0.85}-\rho_{1.65}\right) /\left(\rho_{0.85}+\rho_{1.65}\right)$ where $\rho_{1.65}$ is the reflectance of a shortwave-infrared band at about $1.65 \mu \mathrm{m}$ wavelength. In another study, Hunt and Rock (1989) showed that the moisture stress index (MSI):

$\mathrm{MSI}=\rho_{1.65} / \rho_{0.85}$

is a function of leaf EWT for a wide range of leaf morphologies. However, MSI is inversely related to leaf EWT and thus may cause more confusion than normalized difference indices. NDII is equal to $(1-\mathrm{MSI}) /(1+\mathrm{MSI})$, so there is a direct, non-linear relationship between these two indices. NDII linearly increases with canopy EWT at low canopy EWT (Ceccato et al., 2002; Davidson et al., 2006; Jackson et al., 2004), so NDII is preferable to MSI as a vegetation index. MODIS has another band at about $1.24 \mu \mathrm{m}$ wavelength which also may be used to estimate canopy EWT (Gao, 1996):

$\mathrm{NDWI}=\left(\rho_{0.85}-\rho_{1.24}\right) /\left(\rho_{0.85}+\rho_{1.24}\right)$

where NDWI is the normalized difference water index and $\rho_{1.24}$ is the reflectance at about $1.24 \mu \mathrm{m}$ wavelength. Gao (1996) has important, specific reasons for using $\rho_{1.24}$ instead of $\rho_{1.65}$, so NDWI is not synonymous with NDII. Because Landsat 5 TM does not have a band in the $1.24 \mu \mathrm{m}$ wavelength region, NDWI was not used in this study.

\subsection{Vegetation classification}

Digital elevation data $(90 \mathrm{~m})$ were acquired for the Sonora study areas from the North American Monsoon Experiment data center at the Earth Observing Laboratory, National Center for Atmospheric Research (Boulder, CO, USA, http://data.eol.ucar. edu/codiac/ds_proj?NAME). Digital elevation data $(30 \mathrm{~m})$ were obtained for the Arizona study area from GeoCommunity at Qlinks Media Group (Niceville, FL, USA, http://data.geocomm. com). Using elevation, slope and maximum curvature were calculated within the Environment for Visualizing Images (ENVI version 4.0, Research Systems, Inc., Boulder, Colorado, USA) to delineate riparian areas from upland areas. Rather than use band reflectances for classification, NDVI and NDII were used because these indices reduced the effects of the substantial variation in soil background reflectances. Furthermore, the overall mean of NDVI and NDII and the maximum difference of NDVI and NDII over the three dates were calculated in ENVI. A 15-band dataset was created from the three topographic variables, the three dates of NDVI, the three dates of NDII, threedate mean NDVI and NDII, three-date maximum NDVI and NDII, and the maximum difference of NDVI and NDII for classification of vegetation types.

A decision tree (Belward \& de Hoyos, 1987; Bolstad \& Lillesand, 1992; Friedl \& Brodley, 1997; Lloyd, 1990; Running et al., 1995) was used to classify the study areas and the surrounding region using ENVI. Most decision-tree classifications use statistical procedures on training data to develop rules for each node (Friedl \& Brodley, 1997). Here the rules were developed manually to have the fewest number of nodes by comparing the classification to the ground data and general vegetation maps for the Arizona and Sonora study areas (Jackson, 2004). 
Ground data used to develop the classification were the vegetation plots in the Arizona and Sonora study areas (Table 1). The following were initially determined to be the major landcover classes and were selected for the initial classification: (1) water, (2) unvegetated, (3) desert shrublands, (4) grassland, (5) riparian mesquite, (6) riparian woodland, (7) evergreen oak woodland, (8) evergreen needle-leaf woodland, (9) subtropical shrubland, and (10) agriculture.

Desert shrublands are most common vegetation type at the lower, non-riparian lands in Arizona and Sonora, with creosote bush, deciduous leguminous shrubs and desert succulents commonly occurring (Table 2). There are three different types of grassland depending on elevation: riparian sacaton, lower elevation black grama, and higher elevation sideoats grama (Table 2). The grasslands and desert shrublands have a very gradual transition and are common of the Sonoran and Chihuahuan deserts (MacMahon, 2000). Riparian communities are mesquite and deciduous woodlands (Table 2); mesquite occurs throughout the study areas, both upland and riparian, but in the riparian zone it forms small trees whereas in the uplands it is similar in stature and density to other desert leguminous shrubs. At higher elevations are evergreen oak and pine woodlands, with a significant understory of sideoats grama. Subtropical shrubland is a drought-deciduous vegetation community in Sonora, which leafs out during the summer monsoon, and occurs at elevations between the desert shrublands and oak woodlands. One of the differences between the desert shrubland and subtropical shrubland was the substitution of the saguaro cactus with the organ-pipe cactus (Table 2). Agriculture is a mixed landcover class, which included different irrigated crops at different stages of development.

The soil moisture plots sampled during SMEX04 (Cosh et al., 2008-this issue; Vivoni et al., 2008-this issue) were used to assess the accuracy of the classification. Accuracy was assessed using producer, user and overall accuracies (Congalton $\&$ Green, 1999). Because the soil moisture plots were not

Table 2

Common names and species names representative of some vegetation classes

\begin{tabular}{lll}
\hline Common name & Species name & Vegetation class \\
\hline Creosote bush & Larrea tridentata & Shrub \\
Cat's claw & Acacia greggii & Shrub \\
White thorn & Acacia constricta & Shrub \\
Ironwood & Olneya tesota & Shrub \\
Beargrass (succulent) & Nolina microcarpa & Shrub \\
Saguaro (succulent) & Cereus giganteus & Shrub \\
Yucca (succulent) & Yucca schottii & Shrub \\
Ephedra (succulent) & Ephedra trifurca & Shrub \\
Rabbitbrush & Chrysothamnus & Shrub \\
& nauseosus & \\
Sacaton & Sporobolus wrightii & Grass \\
Black grama & Bouteloua eriopoda & Grass \\
Sideoats grama & Bouteloua curtipendula & Grass \\
Mesquite & Prosopis velutina & Riparian Mesquite or Shrub \\
Organ-pipe cactus & Stenocereus thurberi & Subtropical \\
Willow & Salix spp. & Riparian Wood \\
Cottonwood & Populus tremontii & Riparian Wood \\
Pine & Pinus spp. & Evergreen \\
Oak & Quercus spp. & Evergreen \\
\hline
\end{tabular}

Table 3

Site leaf area index (LAI), leaf equivalent water thickness (EWT), and canopy EWT

\begin{tabular}{|c|c|c|c|c|}
\hline Site name (class) & $\begin{array}{l}\text { LAI } \\
\text { (LAI-2000) }\end{array}$ & $\begin{array}{l}\text { LAI } \\
\text { (fisheye) }\end{array}$ & $\begin{array}{l}\text { Leaf EWT } \\
(\mathrm{mm})\end{array}$ & $\begin{array}{l}\text { Canopy EWT } \\
\left(\mathrm{kg} \mathrm{m}^{-2}\right)\end{array}$ \\
\hline AZ Maize (agriculture) & 5.33 & 7.82 & 0.11 & 0.72 \\
\hline AZ Chili (agriculture) & 1.63 & 2.03 & 0.21 & 0.38 \\
\hline AZ Kendell (grass) & 0.25 & 0.09 & 0.16 & 0.03 \\
\hline AZ Stronghold (grass) & 0.24 & 0.21 & 0.14 & 0.03 \\
\hline $\begin{array}{l}\text { AZ Lewis Springs } \\
\text { (sacaton) }\end{array}$ & - & 1.15 & $0.19^{\mathrm{a}}$ & 0.22 \\
\hline AZ San Pedro (sacaton) & 1.10 & 1.21 & 0.19 & 0.22 \\
\hline AZ Lucky Hills (shrub) & - & 0.27 & 0.27 & 0.07 \\
\hline AZ RG13 (shrub) & 0.32 & 0.36 & $0.19^{\mathrm{b}}$ & 0.07 \\
\hline $\begin{array}{l}\text { AZ Kendell } \\
\text { (whitethorn shrub) }\end{array}$ & 0.29 & 0.27 & 0.19 & 0.05 \\
\hline $\begin{array}{l}\text { AZ RG57 } \\
\text { (beargrass shrub) }\end{array}$ & 0.20 & - & 0.63 & 0.13 \\
\hline $\begin{array}{l}\text { AZ San Pedro } \\
\quad \text { (rabbitbrush shrub) }\end{array}$ & 0.40 & - & 0.69 & 0.27 \\
\hline $\begin{array}{l}\text { AZ Lewis Springs } \\
\text { (rip. mesquite) }\end{array}$ & 1.25 & 1.38 & 0.16 & 0.21 \\
\hline $\begin{array}{l}\text { AZ San Pedro } \\
\text { (riparian wood) }\end{array}$ & - & 2.41 & $0.20^{\mathrm{c}}$ & 0.48 \\
\hline $\begin{array}{l}\text { AZ Stronghold South } \\
\text { (oak) }\end{array}$ & - & 0.98 & 0.13 & 0.13 \\
\hline $\begin{array}{l}\text { AZ Stronghold North } \\
\text { (oak) }\end{array}$ & 1.16 & 0.98 & 0.14 & 0.14 \\
\hline SO 134 (oak) & - & 0.69 & 0.11 & 0.08 \\
\hline SO 135 (mesquiteshrub) & - & 1.98 & 0.14 & 0.28 \\
\hline SO 136 (shrub) & - & 0.60 & 0.16 & 0.10 \\
\hline SO 143 (mesquiteshrub) & - & 0.63 & 0.11 & 0.07 \\
\hline SO TID1 (oak) & - & 0.59 & $0.18^{\mathrm{d}}$ & 0.11 \\
\hline SO TID2 (oak) & - & 1.74 & $0.18^{\mathrm{d}}$ & 0.31 \\
\hline SO TID4 (oak) & - & 0.75 & 0.19 & 0.14 \\
\hline SO TID5 (oak) & - & 1.13 & 0.16 & 0.18 \\
\hline SO TID7 (subtropical) & - & 0.77 & $0.30^{\mathrm{e}}$ & 0.23 \\
\hline SO TID13 (subtropical) & - & 1.17 & $0.30^{\mathrm{e}}$ & 0.35 \\
\hline
\end{tabular}

LAI $\left(\mathrm{m}^{2} \mathrm{~m}^{-2}\right)$ was estimated using the LICOR Plant Canopy Analyzer (LAI2000) or canopy hemispherical (fisheye) photographs corrected to expected value for the LAI-2000, Fig. 1). When both the LAI-2000 and fisheye photographs were used, final plot LAI was the mean of the two methods.

a Value from AZ San Pedro sacaton was used.

${ }^{\mathrm{b}}$ Value from AZ Kendell white thorn was used.

${ }^{c}$ No available data, $0.20 \mathrm{~mm}$ from Populus deltoides (E. R. Hunt, personal communication).

d Average value was used for SO TID-4 and SO TID-5.

e No available data, $0.30 \mathrm{~mm}$ from Sims and Gammon (2003).

selected to have a range of vegetation types, there were an insufficient number of points for most vegetation classes; thus, the vegetation plots were included the accuracy assessment.

\section{Results and discussion}

\subsection{NDII and canopy EWT}

LAI was generally low except for irrigated agricultural areas and riparian woodlands (Table 3), which was expected due to the desert climate. Also, LAI (Table 3) was correlated with the cover of green vegetation (Table 1 ) with $r=0.59$, which was significant at $P<0.005$. For non-succulent vegetation types, leaf EWT ranged from $0.11 \mathrm{~mm}$ to $0.27 \mathrm{~mm}$, in the range found for many leaves (Hunt \& Rock, 1989; Sims \& Gamon 2003). 


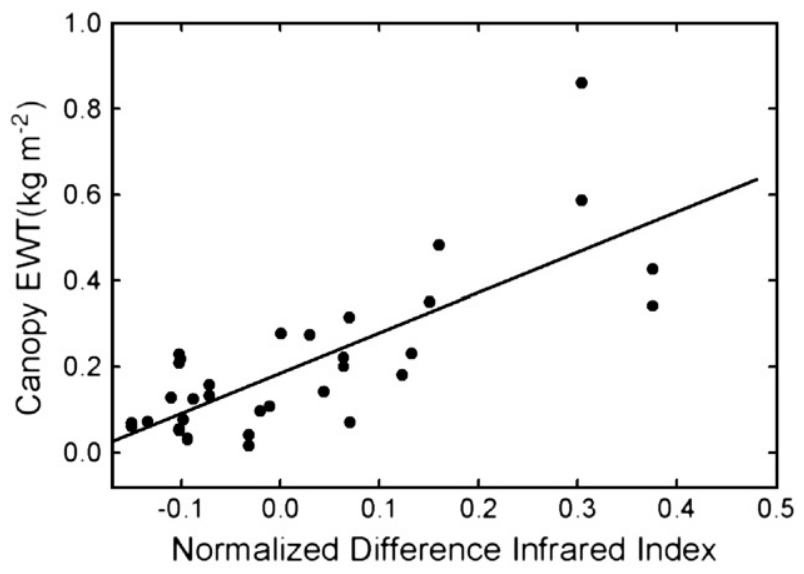

Fig. 3. Canopy equivalent water thickness (EWT) versus July-August average Normalized Difference Infrared Index (NDII). The equation of the simple linear regression is $y=0.938 x+0.185$, with an $R^{2}$ of 0.601 and a standard error of the $y$ estimate of $0.133 \mathrm{~mm}$.

The variation in LAI and leaf EWT created a large range in canopy EWT from 0.01 to $0.75 \mathrm{~kg} \mathrm{~m}^{-2}$ (Table 3).

The dates for the July and August Landsat TM images occurred before and after, respectively, the dates for the SMEX04 fieldwork. Therefore, the average NDII from the July and August imagery were compared to the vegetation data (Table 3). NDII was linearly related to canopy EWT (Fig. 3). This regression equation was used to estimate canopy EWT for the three dates of Landsat TM imagery (Fig. 4). MSI and NDVI did not have as high $R^{2}$ or as low standard error as NDII for estimating canopy EWT (data not shown).

Two recent studies have related canopy EWT to vegetation indices using $\rho_{1.65}$ : Ceccato et al. (2002), and Davidson et al.
(2006). Pietro Ceccato (personal communication) and Andrew Davidson (personal communication) provided more information on their findings, so that we were able to compare our results with theirs. The regression equations between NDII and canopy EWT from these two studies were not significantly different from that in Fig. 3 using a dummy variable regression ( $P=0.536$ and $P=0.076$ for Ceccato et al. and Davidson et al., respectively). Thus, Ceccato et al. (2002) and Davidson et al. (2006) together with this study suggest that the canopy EWTNDII relationship is robust. Hunt (1991) estimated very large canopy EWT during the Oregon Transect Terrestrial Ecosystem Research project, and the relationship between canopy EWT and NDII was different from Fig. 3, Ceccato et al. (2002), and Davidson et al. (2006). From Hunt (1991), it is likely that the canopy EWT-NDII relationship becomes saturated at high canopy EWT.

The standard error of the $y$ estimate for the regression equation in Fig. 3 is $0.133 \mathrm{~mm}$, which is somewhat less than the average of leaf EWT (Table 3). Therefore, the relationship between Landsat TM NDII and canopy EWT is not useful for detecting the incipient stages of drought stress because most of the leaf water would need to be lost before detection of stress, which supports Hunt and Rock's (1989) conclusion using MSI (Eq. (7)). However, $\pm 0.133 \mathrm{~mm}$ is equivalent to an accuracy of 0.5 to $1 \mathrm{~m}^{2} \mathrm{~m}^{-2} \mathrm{LAI}$ for non-succulent species, so the accuracy of NDII may be sufficient for assimilation into algorithms to retrieve soil moisture from microwave remote sensing data.

\subsection{Landcover classification}

SMEX04 vegetation data (Table 1) were used in a preliminary analysis to separate different landcover classes based on
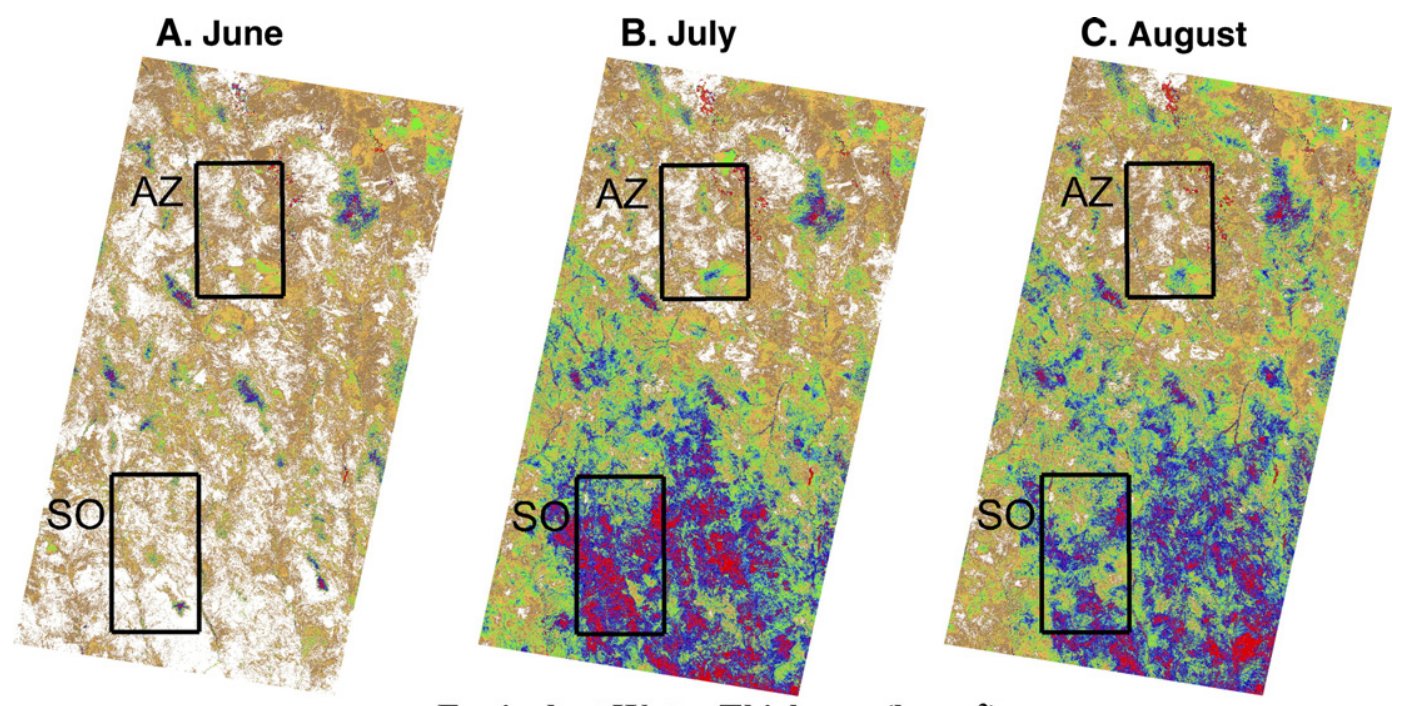

Equivalent Water Thickness $\left(\mathrm{kg} \mathrm{m}^{-2}\right)$
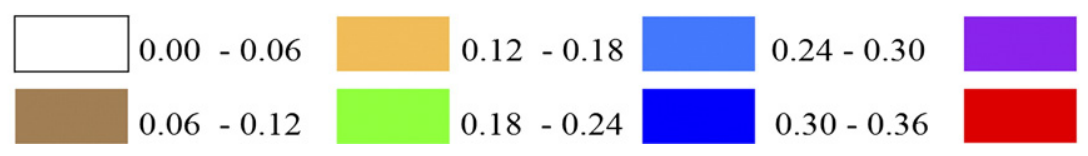

$0.36-0.42$ $0.42-1.00$

Fig. 4. Canopy EWT estimated by NDII from Landsat 5 TM images acquired on (A) June 11, (B) July 29, and (C) August 30, 2004. The regression for the plot data (Fig. 3) was used to estimate canopy EWT. Boxes show the SMEX04 study areas in Arizona and Sonora. 


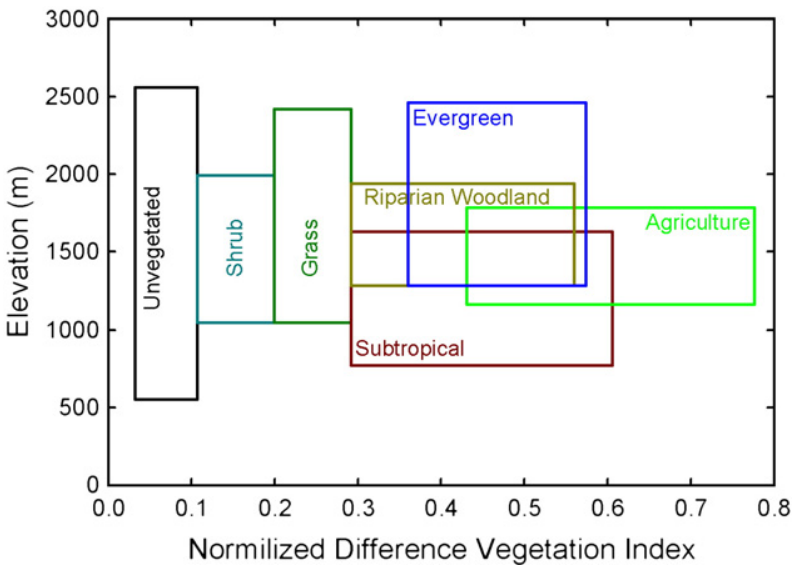

Fig. 5. Relationships of NDVI and elevation for landcover classification based on vegetation sites used for a decision tree classification.

elevation and average NDVI (Fig. 5). Grasslands and shrublands had lower average NDVI whereas other vegetation types had higher average NDVI. NDVI and elevation data from the imagery using known areas of pine woodlands indicated that this landcover class could not be separated from evergreen oak woodlands, so these two classes were combined. Elevation was particularly useful for separating the subtropical shrublands from the higher elevation evergreen oak and pine woodlands (Fig. 5). Agriculture had the highest NDVI (Fig. 5), but the NDVI was highly variable, which was likely due to the three Landsat 5 TM images being acquired at different stages of crop growth.

The first major decision in the regression tree was differentiation between areas of low and high vegetation cover, based on average NDVI (Table 4, Rule 1). Areas with very low average NDVI are either water bodies or playas with no vegetation. Grasslands and shrublands also have low NDVI, and were distinguished based on the green-up of grasslands with the summer monsoon rains (Table 4, Rule 4). Riparian vegetation was first separated using stream channels defined by topography and was not seasonal (Table 4, Rule 5). The amount of NDII and NDVI separate riparian mesquite from riparian woodlands classes (Table 4, Rule 9). Subtropical shrublands are droughtdeciduous and occur only in Mexico, so first a border of latitude was created in northern Sonora, so that areas south of this latitude with a large phenological change in NDVI would be classified as subtropical shrubs (Table 4, Rule 6). Except for the topography, subtropical shrubs show similar NDVI change with crops and NDVI amount with evergreen vegetation. So the use of NDVI change and amount was critical to mask out evergreen and crops respectively to handle the similarities between each

Table 4

Rules for decision tree land cover classification

\begin{tabular}{|c|c|c|c|}
\hline Rule & Conditional statement $^{\mathrm{a}}$ & False & True \\
\hline 1 & $\begin{array}{l}(\text { NDVI-ave }>0.27) \&[(\text { NDVI-ave }>0.32) \\
((\text { NDVI } 211-\text { NDVL_163 })>0.195)]^{b}\end{array}$ & Rule 2 & Rule 5 \\
\hline 2 & NDVI-ave $>0.13$ & Rule 3 & Rule 4 \\
\hline 4 & $($ NDVI-ave $<0.22) \&(\text { NDVI-max-diff }<0.08)^{c}$ & Grass & Shrub \\
\hline 5 & $\begin{array}{l}{[(\text { slope }<5) \& \quad(\text { DEM }<1550 \mid \text { max-curv }<30.3)] \&} \\
{[(\text { NDII-max-diff }<0.26) \&(\text { NDVI-ave }<0.53)] \&} \\
{[(\text { NDVI_211-NDVI_163) }<0.20 \&(\text { NDVI-max }} \\
- \text { NDVI_163 })<0.275]^{\mathrm{d}}\end{array}$ & Rule 6 & Rule 9 \\
\hline 6 & $\begin{array}{l}{[(\text { border }=1) \&(\text { DEM }<1550) \&(\text { max-curv }<30.3)] \&} \\
{[((\text { NDVI_211 }- \text { NDVI_163) }>0.23)] \&[(\text { NDVI- }} \\
\text { ave }>0.40) \&(\text { NDVL_163 }<0.31)]^{\mathrm{e}}\end{array}$ & Rule 7 & Subtropical \\
\hline 7 & $\begin{array}{l}{[(\mathrm{DEM}<1550) \& \quad(\text { slope }<1.5)] \& \quad\{(\text { NDVI- }} \\
\text { ave }>0.40) \&[(\text { NDVI-max-diff }>0.45) \mid(\text { NDVI- } \\
\max >0.80) \mid(\text { NDII-max }>0.40) \mid(\text { NDII-max }- \\
\operatorname{diff}>0.50)]\}^{f}\end{array}$ & Rule 8 & Agriculture \\
\hline 9 & (NDIL_163<0.04 ) \& (NDVL_163<0.47) & Riparian Wood & Mesquite \\
\hline
\end{tabular}

${ }^{\text {a }}$ Symbols and variable names and (\&); or, $(\mid)$; digital elevation model (DEM, m); normalized difference vegetation index (NDVI); normalized difference infrared index (NDII); slope calculated from DEM (slope, \%); maximum curvature calculated from DEM (max-curv, dimensionless); division between semiarid and subtropical vegetation types(border); average NDVI for the three TM images (NDVI-ave); maximum NDVI for the three TM images (NDVI-max); maximum difference of NDVI among the three TM images (NDVI-max-diff); average NDII for the three TM images (NDII-ave); maximum NDII for the three TM images (NDII-max); maximum difference of NDII among the three TM images (NDII-max-diff); yearday 163 (June 11) value, yearday 211 (July 29) value; yearday 243 (August 30) value.

${ }^{\mathrm{b}}$ Rule 1: Average NDVI separates low and high vegetation cover.

${ }^{c}$ Rule 4: Seasonal increase in NDVI separates grasses from shrubs.

${ }^{\mathrm{d}}$ Rule 5: Stream channels and little change over time separates riparian vegatation from other vegetation types.

${ }^{\mathrm{e}}$ Rule 6: Subtropical shrubs are highly seasonal and occur only in the Sonoran study area.

${ }^{\mathrm{f}}$ Rule 7: Agriculture is highly seasonal and occur on relatively flat land.

g Rule 8: Evergreen oaks and conifers occur at different elevations on a south to north gradient due to differences in precipitation. 


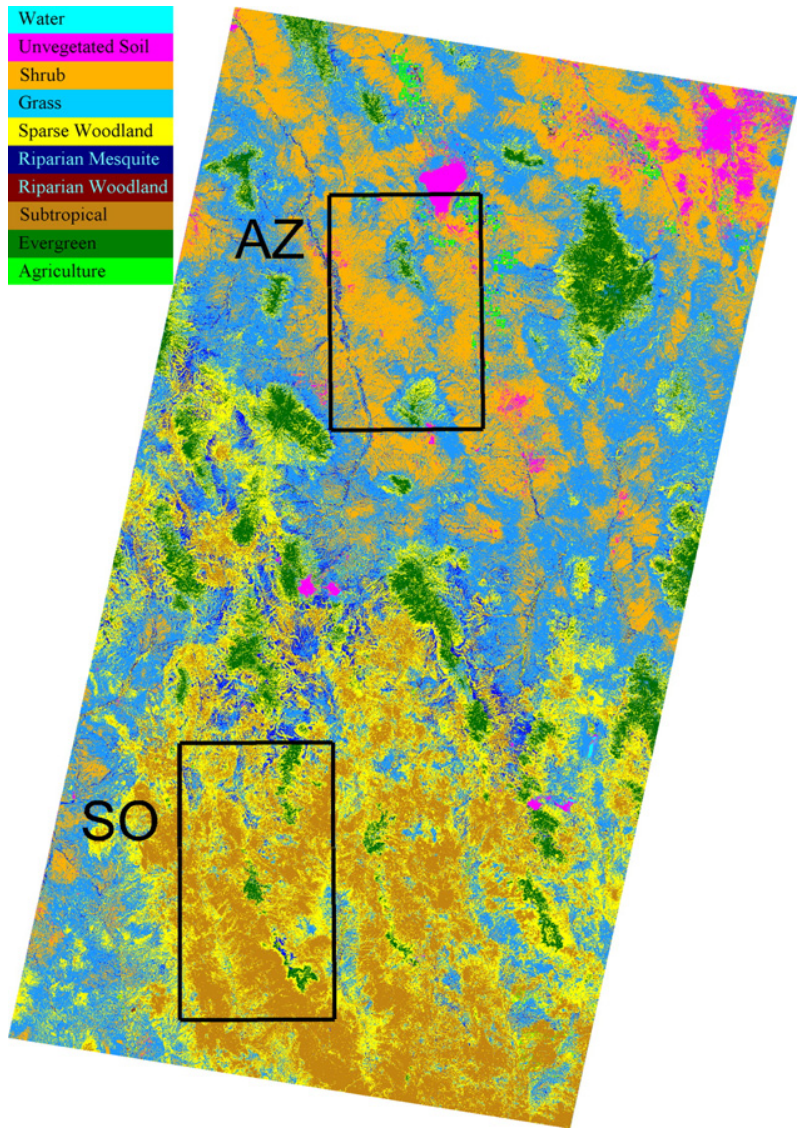

Fig. 6. Landcover classification from three dates of Landsat 5 Thematic Mapper imagery with the SMEX04 study areas shown in boxes.

class, which resulted in a variety of rules (Table 4, Rule 7). However, combining the various crop types into one class resulted in nested statements to separate woods from agricultural fields (Table 4, Rule 7). Growing over a wide range of elevation, evergreen conifer and oak woodlands have three different rules along a south to north precipitation gradient (Table 4, Rule 8).

After the rules for the various landcover classes that were defined during the SMEX04 experiment were applied, there was a large area that remained unclassified. These areas had higher NDVI than shrublands, and lower NDVI than evergreen woodlands, and did not have the strong phenology signal of subtropical shrublands. Therefore, a new class was created, sparse woodlands, which were observed in the field to be dominated by upland mesquite, Acacia shrubs, and ironwood. In the Arizona study area, when these species occurred at low density and at low elevations, these species were classified as desert shrubland (Table 1, AZ Kendell - whitethorn). In the Sonora study area, these species occurred at higher density (Table 1, SO 135, SO 136 and SO 143), leading to higher NDVI.

The final landcover based on the three dates of Landsat $5 \mathrm{TM}$ data is shown in Fig. 6. The various classes show the general trends of the vegetation with elevation as observed in the Arizona study area. The dominant landcover class in the Arizona study area was desert shrub, and the dominant landcover class in the Sonora study area was subtropical shrub. However, $37 \%$ of the Sonora study area was classified as sparse woodland, whereas this landcover class was only $5 \%$ of the Arizona study area (Fig. 6).

The overall accuracy of the decision-tree classification was only $70 \%$ (Table 5). The overall accuracy is low, in part because the sparse woodlands were not defined a priori, and thus, were treated as classification errors. By including sparse woodlands as a separate land-cover class before data collection, the overall accuracy increases to $75 \%$. For the two landcover classes that had a large number of samples, desert shrublands in the Arizona study area and subtropical shrublands in the Sonora study area, the user and producer accuracies were about $80 \%$ to $90 \%$ (Table 5). Grasslands were poorly differentiated with a producer accuracy of $44 \%$ and a user accuracy of $18 \%$. The poor classification of grasslands was caused by confusion with

Table 5

Accuracy assessment for landcover classification

\begin{tabular}{|c|c|c|c|c|c|c|c|c|c|}
\hline \multirow[t]{2}{*}{ Class } & \multicolumn{9}{|c|}{ Ground data } \\
\hline & Grass & Shrub & R. Mesquite $^{\mathrm{a}}$ & R. Wood ${ }^{\mathrm{b}}$ & Evergreen $^{c}$ & Agriculture & Subtropical & Total & User Accuracy (\%) \\
\hline Grass & 4 & 14 & 1 & - & 3 & - & - & 22 & 18 \\
\hline R. Mesquite & - & 1 & - & - & - & - & - & 1 & 0 \\
\hline R. Wood & - & - & 1 & - & - & - & - & 1 & 0 \\
\hline Evergreen & - & - & - & - & 2 & - & - & 2 & 100 \\
\hline Agriculture & - & - & - & - & - & 1 & - & 1 & 100 \\
\hline Total & 9 & 113 & 5 & 2 & 11 & 2 & 23 & 165 & \\
\hline Producer Accuracy (\%) & 44 & 79 & 0 & 0 & 18 & 50 & 87 & & \\
\hline Overall Accuracy (\%) & & & & & & & & & 70 \\
\hline
\end{tabular}

The ground data include the vegetation sites (Table 1) that were used for training and the soil moisture sites from SMEX04.

a Riparian mesquite.

b Riparian woodland (cottonwood-willow).

c Combined evergreen oak and pine woodlands.

d New intermediate category, sparse woodland. 


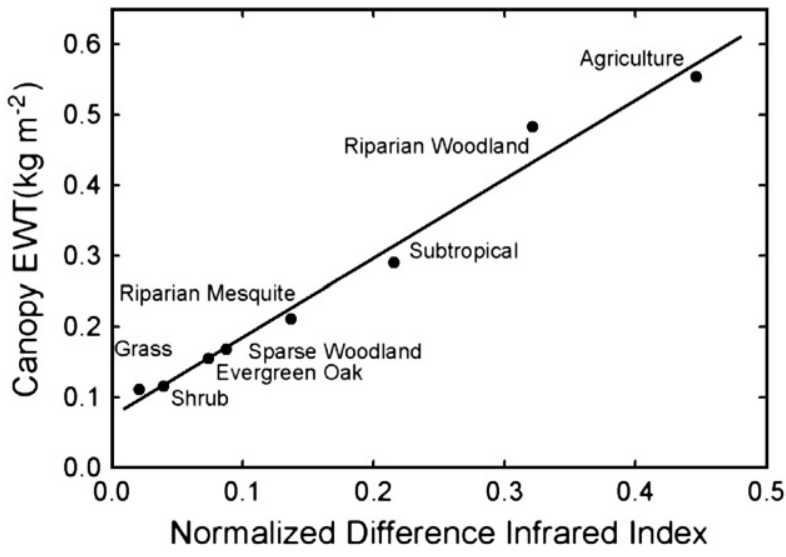

Fig. 7. Landcover-average canopy EWT versus landcover-average NDII. The equation of the simple linear regression is $y=1.23 x+0.0722$, with an $R^{2}$ of 0.980 and a standard error of the $y$ estimate of 0.081 .

shrublands in the Arizona study area (Table 5). Evergreen woodlands also were poorly classified, with a producer accuracy of $18 \%$. All landcover classes had some confusion with the residual class, sparse woodland (Table 5), particularly the desert shrubland in the Sonora study area, indicating the transitional nature of the sparse woodland class.

It was expected that there would be stronger differences among the vegetation types based on phenology. However, the summer monsoon started late in 2004, which may have reduced the expected phenological differences. Elevation data had to be added to the classification, as a proxy for precipitation, because of reduced rainfall in the summer of 2004.

\subsection{Comparison of canopy EWT from NDII and landcover}

When canopy EWT and July-August average NDII were averaged by landcover class, there was a strong linear relationship between canopy EWT and NDII (Fig. 7). The JulyAugust average was selected because this time period represents peak LAI as the result of the summer monsoon and the imagery brackets the time the ground data were collected. Since there was no sparse woodland class sampled during SMEX04, canopy EWT and NDII were estimated with the average values of shrubland, grassland, riparian woodland, evergreen woodland, and subtropical shrubland. Although the $R^{2}$ of Fig. 7 was much higher than Fig. 3, the regression equations were not significantly different, because the same data were used for both regressions. The important point of Fig. 7 is that predictions of canopy EWT based on landcover-class averages appear to be more accurate than predictions based on NDII, but this is simply due to averaging plot variability within the data points used for each landcover class.

Canopy EWT predicted from landcover class were different to the canopy EWT from NDII, particularly in the desert shrublands and evergreen woodlands of the Arizona study area and in the subtropical shrublands in the Sonora study area (Fig. 8). The differences in canopy EWT between the two methods are shown in Fig. 9. Most of the two TM images have

\section{A. Landcover}

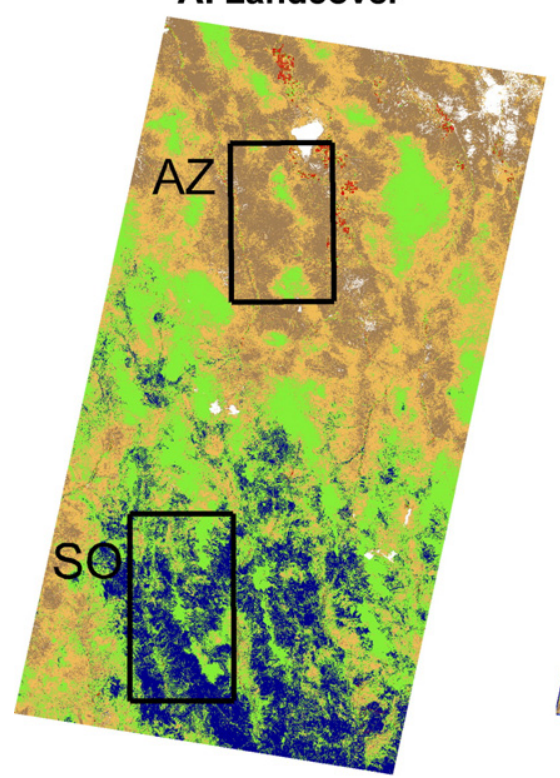

B. July-August average

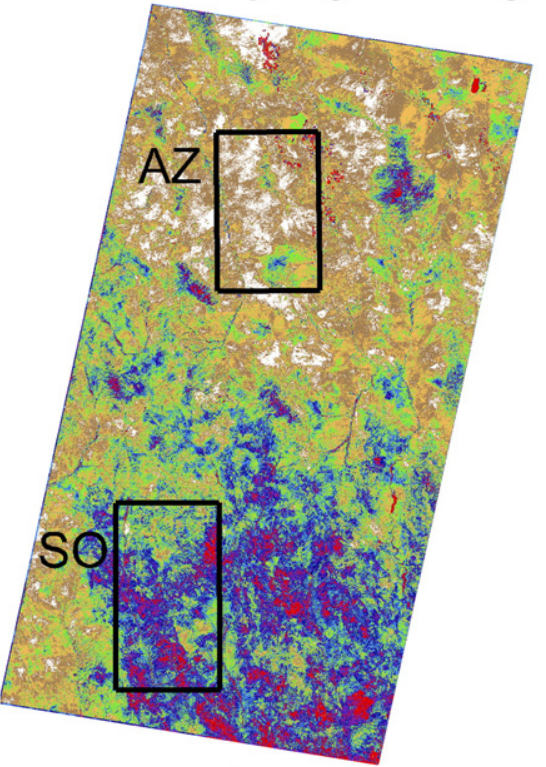

Equivalent Water Thickness ( $\left.\mathrm{kg} \mathrm{m}^{-2}\right)$

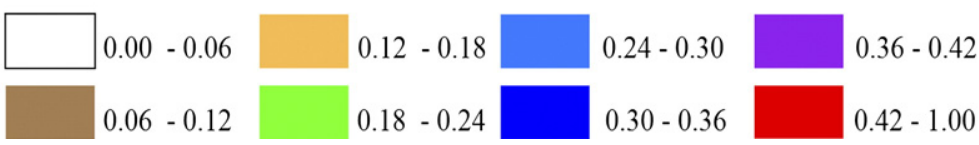

Fig. 8. Canopy EWT estimated by (A) Landcover and (B) July-August average NDII. Class averages were used to estimate EWT for panel A and the regression from the plot data (Fig. 3) was used for panel B. Boxes show the SMEX04 study areas in Arizona and Sonora. 
close agreement between canopy EWT predicted from landcover class and from NDII. The errors for the evergreen woodlands and subtropical shrublands are large compared to the standard error in the regression of Fig. 4.

These errors may be from the lack of representative sampling done during SMEX04 for subtropical shrublands; however, there were many plots of evergreen oaks woodlands in both the Arizona and Sonora study areas (Table 1). The value for leaf EWT of subtropical shrublands was assumed to be $0.3 \mathrm{~mm}$ (Table 2), which is within the range found for drought-deciduous shrubs in the Southern California Chaparral (Sims \& Gamon, 2003). Other large errors were found for bare soil, playas and active mines, for which the landcover classification assumed a value of $0 \mathrm{~mm}$ for canopy EWT. We hypothesize that the high values of canopy EWT for non-vegetated surfaces may simply result from these surfaces being wet or from mineral absorptions (Ben-Dor, 2002).

There is a large range of overlap in NDII among the various landcover classes (Fig. 10). Variation in NDVI shows a similar pattern of large variation (data not shown). Some of the variation in NDII can be attributed to errors in the landcover classification (Table 5); however, much of the range of variation is probably attributed to differences in LAI, because the field data measured during SMEX04 had similar changes in LAI (Table 2).

For some landcover classes such as agriculture, seasonal growth results in large increases in LAI and canopy EWT (Anderson et al., 2004; Doraiswamy et al., 2004; Jackson et al., 2004), so landcover average EWT would not be appropriate. For other remote sensing applications such as estimating fuel dry-

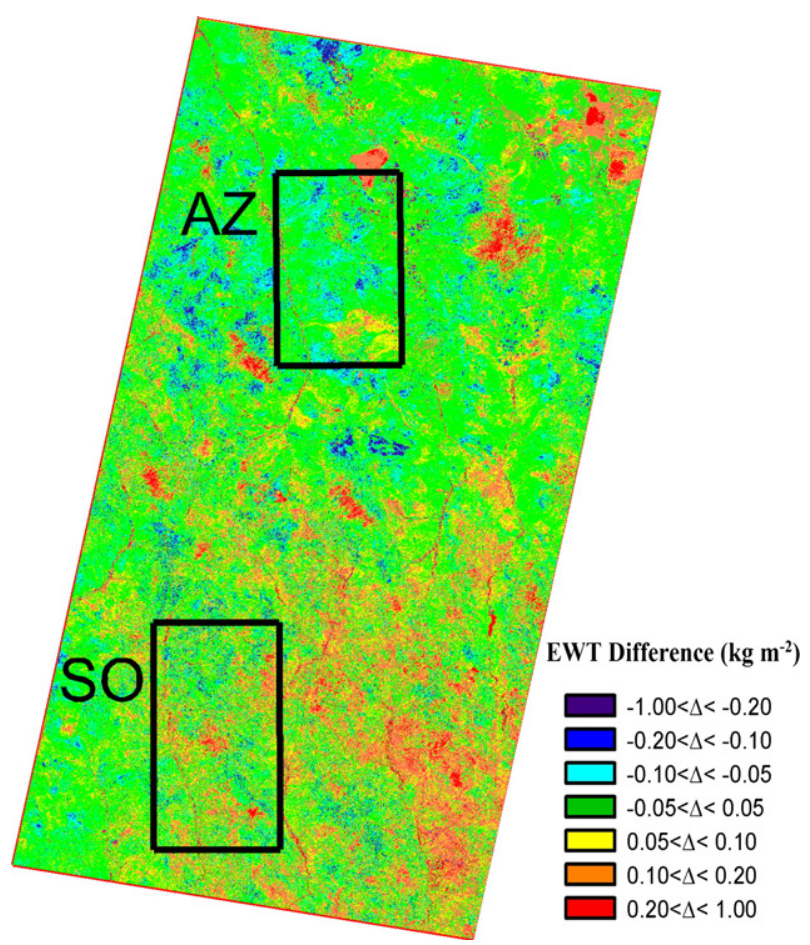

Fig. 9. The absolute difference in canopy EWT estimated from the July-August average NDII and landcover. Boxes show the SMEX04 study areas in Arizona and Sonora.

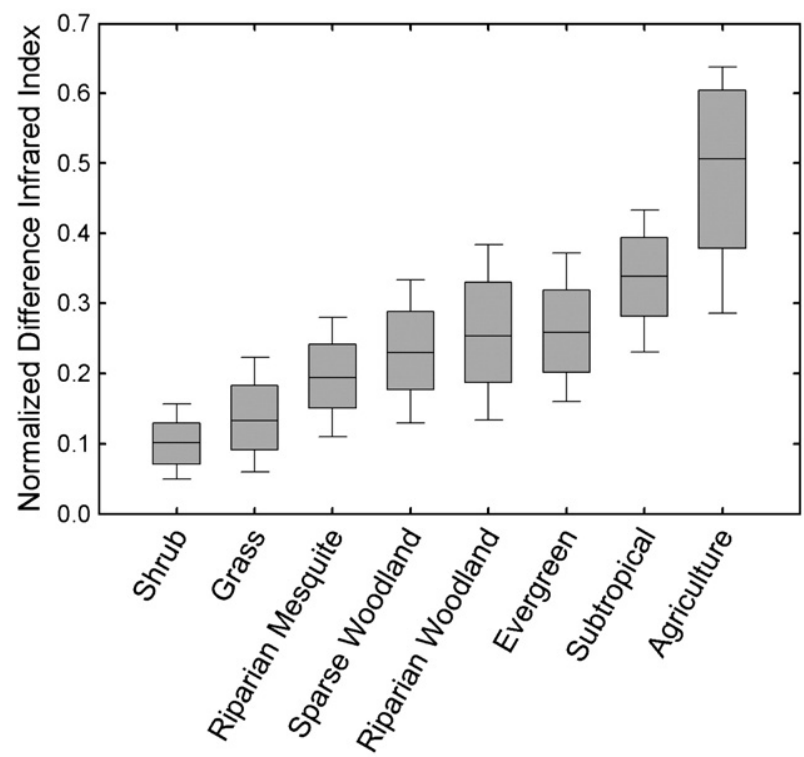

Fig. 10. Percentiles of NDII for each landcover class. The center line is the median, the ends of the boxes are the 25 th and 75 th percentiles, and the error bars are the 10th and 90th percentiles.

ness for wildfire potential, seasonal variation of canopy EWT is necessary. For both the Arizona and Sonora study areas, NDII tracked changes in canopy EWT over the summer, monsoonal growing season (Fig. 4), which would not be possible with the landcover-based canopy EWT. After the initial growth phase of perennial vegetation, patterns of LAI are related to precipitation and soil water holding capacity (Hoff \& Rambal, 2003; Nemani \& Running, 1989; Woodward, 1987); thus, landcover average EWT is actually site dependent. Broad variation in NDII in each landcover class (Fig. 10) suggests that even at the peak of the growing season, a biophysical relationship between NDII and canopy EWT would be preferable to landcover averages for mapping vegetation water content for soil moisture retrievals from microwave data.

\section{Conclusions}

Using vegetation data collected during SMEX04, two alternatives developed for canopy EWT, one based upon NDII and the other using landcover class. Similar to leaf studies, changes in shortwave-infrared reflectances at about $1.65 \mu \mathrm{m}$ wavelength compared to near-infrared reflectances are probably directly related to canopy EWT, as indicated by extensive simulations using canopy radiative transfer models (Baret \& Fourty, 1997; Ceccato et al., 2001, 2002). The linear relationship between NDII and canopy EWT found here was not significantly different from other studies over the same range of canopy EWT (Ceccato et al., 2002; Davidson et al., 2006); thus, NDII from various sensors, such as MODIS, may be able to provide a global estimate of canopy EWT. Whereas landcover class was a relatively poor predictor of canopy EWT, landcover class will be very important for estimating total vegetation water content, because considerable liquid water is contained in the non-foliar components of vegetation. Although we used NDII for this 
study, we expect similar conclusions for other vegetation indices based on the spectral absorption features of liquid water.

\section{Acknowledgments}

We thank the following for participating with the SMEX04 Vegetation Science Team (in alphabetical order): David Darling (U.C. Davis), Charles Fernandes (ESRI, Redlands, CA), John Kefauver (U.C. Davis), Ho-Jin Kim (U. Arizona), Youngwook Kim (U. Arizona), Lin Li (U. Indiana), Pam Nagler (U. Arizona), Jose Ramon (U. Leon, Spain), David Riaño (U.C. Davis), John Schroeder (U. Arizona), Nathannich Sirikul (U. Arizona), Ed Tom (U.C. Davis), and Phil Valco (U.C. Davis). We also thank Ed Glenn and Alfredo Huete from the University of Arizona for allowing the use of their facilities. Furthermore, we thank Lynn McKee, Mike Cosh, and Rajat Bindlish of the USDA-ARS Hydrology Laboratory for coordinating with SMEX04 Soil Moisture Team activities. We thank Iliana Mladenova for helping in calibration of the digital hemispherical photographs. Especially, we thank Andrew Davidson and Pietro Ceccato for providing additional details and data from their published studies. Finally, we thank Dr. Adriaan van de Griend from Vrije University, Amsterdam, The Netherlands, for supervising M.T. Yilmaz's thesis research. This research was sponsored by NASA Research Agreement 009767-01, "Global Estimation of Canopy Water Content," to University of California, Davis.

\section{References}

Adler-Golden, S. M., Matthew, M. W., Bernstein, L. S., Levine, R. Y., Berk, A., Richtsmeier, S. C., et al. (1999). Atmospheric correction for short-wave spectral imagery based on MODTRAN4. In M. R. Descour S. S. Shen (Eds.), Imaging spectrometry V, SPIE proceedings, Vol. 3753 (pp. 61-69) Bellingham, Washington: International Society of Optical Engineers

Anderson, M. C., Neale, C. M. U., Li, F., Norman, J. M., Kustas, W. P., Jayanthi, H., et al. (2004). Upscaling ground observations of vegetation water content, canopy height, and leaf area index during SMEX02 using aircraft and Landsat imagery. Remote Sensing of Environment, 92, 447-464.

Baret, F., \& Fourty, T. (1997). Estimation of leaf water content and specific leaf weight from reflectance and transmittance measurements. Agronomie, 17, $455-464$.

Baret, F., \& Guyot, G. (1991). Potentials and limits of vegetation indices for LAI and APAR assessment. Remote Sensing of Environment, 35, 161-173.

Belward, A. S., \& de Hoyos, A. (1987). A comparison of supervised maximum likelihood and decision tree classification for crop cover estimation from multitemporal Landsat MSS data. International Journal of Remote Sensing, $8,229-235$.

Ben-Dor, E. (2002). Quantitative remote sensing of soil properties. Advances in Agronomy, 75, 173-244.

Bolstad, P. V., \& Lillesand, T. M. (1992). Rule-based classification models: Flexible integration of satellite imagery and thematic spatial data. Photogrammetric Engineering \& Remote Sensing, 58, 965-971.

Ceccato, P., Flasse, S., \& Gregoire, J. -M. (2002). Designing a spectral index to estimate vegetation water content from remote sensing data: Part 2. Validations and applications. Remote Sensing of Environment, 82, 198-207.

Ceccato, P., Flasse, S., Tarantola, S., Jacquemoud, S., \& Gregoire, J. -M. (2001). Detecting vegetation leaf water content using reflectance in the optical domain. Remote Sensing of Environment, 77, 22-33.

Chander, G., \& Markham, B. (2003). Revised Landsat 5 TM radiometric calibration procedures and post-calibration dynamic ranges. IEEE Transactions on Geoscience and Remote Sensing, 41, 2674-2677.
Chen, D., Huang, J., \& Jackson, T. J. (2005). Vegetation water content estimation for corn and soybeans using spectral indices from MODIS near- and short-wave infrared bands. Remote Sensing of Environment, 98, 225-236.

Chuvieco, E., Riaño, D., Aguado, I., \& Cocero, D. (2002). Estimation of fuel moisture content from multitemporal analysis of Landsat Thematic Mapper reflectance data: applications in fire danger assessment. International Journal of Remote Sensing, 23, 2145-2162.

Congalton, R. G., \& Green, K. (1999). Assessing the accuracy of remotely sensed data: Principles and practices. Boca Raton, Florida: Lewis Publishers.

Cosh, M. H., Jackson, T. J., Moran, S., \& Bindlish, R. (2008). Temporal persistence and stability of surface soil moisture in a semi-arid watershed. Remote Sensing of Environment, 112, 304-313 (this issue).

Danson, F. M., Steven, M. D., Malthus, T. J., \& Clark, J. A. (1992). High spectral resolution data for determining leaf water content. International Journal of Remote Sensing, 13, 461-470.

Datt, B. (1999). Remote sensing of water content in Eucalyptus leaves. Australian Journal of Botany, 47, 909-923.

Davidson, A., Wang, S., \& Wilmshurst, J. (2006). Remote sensing of grassland-shrubland vegetation water content in the shortwave domain. International Journal of Applied Earth Observation and Geoinformation, 8, 225-236.

Dennison, P. E., Roberts, D. A., Peterson, S. H., \& Rechel, J. (2005). Use of normalized difference water index for monitoring live fuel moisture. International Journal of Remote Sensing, 26, 1035-1042.

Doraiswamy, P. C., Hatfield, J. L., Jackson, T. J., Akhmedov, B., Preuger, J., \& Stern, A. (2004). Crop condition and yield simulations using Landsat and MODIS. Remote Sensing of Environment, 92, 548-559.

Fensholt, R., \& Sandholt, I. (2003). Derivation of a shortwave infrared stress index from MODIS near-and shortwave infrared data in a semiarid environment. Remote Sensing of Environment, 87, 111-121.

Franklin, S. E., Lavigne, M. B., Deuling, M. J., Wulder, M. A., \& Hunt, E. R., Jr. (1997). Estimation of forest leaf area index using remote sensing and GIS data for modelling net primary production. International Journal of Remote Sensing, 18, 3459-3471.

Friedl, M. A., \& Brodley, C. E. (1997). Decision tree classification of land cover from remotely sensed data. Remote Sensing of Environment, 61, 399-409.

Gao, B. -C. (1996). NDWI - A normalized difference water index for remote sensing of vegetation liquid water from space. Remote Sensing of Environment, $58,257-266$.

Hardisky, M. A., Klemas, V., \& Smart, R. M. (1983). The influences of soil salinity, growth form, and leaf moisture on the spectral reflectance of Spartina alterniflora canopies. Photogrammetric Engineering and Remote Sensing, 49, 77-83.

Hoff, C., \& Rambal, S. (2003). An examination of the interaction between climate, soil and leaf area index in a Quercus ilex ecosystem. Annals of Forest Science, 60, 153-161

Hunt, E. R. (1991). Airborne remote sensing of canopy water thickness scaled from leaf spectrometer data. International Journal of Remote Sensing, 12, 643-649.

Hunt, E. R., \& Rock, B. N. (1989). Detection of changes in leaf water content using near and middle-infrared reflectances. Remote Sensing of Environment, 30, 43-54.

Jackson, T. J. (Ed.). (2004). Soil moisture experiments in 2004 (SMEX04) and the North American Monsoon Experiment (NAME), Experiment Plan August 2004 Beltsville, Maryland: USDA ARS Hydrology and Remote Sensing Laboratory (http://www.ars.usda.gov/SP2UserFiles/ad_hoc/ 12650600SoilMoistureProgram/images/ SMEX04/SMEX04EPv12.pdf).

Jackson, T. J., Chen, D., Cosh, M., Li, F., Anderson, M., Walthall, C., et al. (2004). Vegetation water content mapping using Landsat data derived normalized difference water index for corn and soybeans. Remote Sensing of Environment, 92, 475-482.

Lloyd, D. (1990). A phenological classification of terrestrial vegetation cover using shortwave vegetation index imagery. International Journal of Remote Sensing, 11, 2269-2279.

MacMahon, J. A. (2000). Warm deserts. In M. C. Barbour, \& W. D. Billings (Eds.), North American Terrestrial Vegetation (pp. 285-322)., 2nd ed. Cambridge, United Kingdom: Cambridge University Press. 
Maki, M., Ishiahra, M., \& Tamura, M. (2004). Estimation of leaf water status to monitor the risk of forest fires by using remotely sensed imagery. Remote Sensing of Environment, 90, 441-450.

Muchoney, D., \& Strahler, A. (2002). Regional vegetation mapping and direct land surface parameterization from remotely sensed and site data. International Journal of Remote Sensing, 23, 1125-1142.

Mueller-Dombois, D., \& Ellenberg, H. (1974). Aims and methods of vegetation ecology. New York, USA: John Wiley \& Sons.

Nemani, R. R., \& Running, S. W. (1989). Testing a theoretical climate-soil-leaf area hydrologic equilibrium of forests using satellite data and ecosystem simulation. Agricultural and Forest Meteorology, 44, 245-260.

Palmer, K. F., \& Williams, D. (1974). Optical properties of water in the near infrared. Journal of the Optical Society of America, 64, 1107-1110.

Peñuelas, J., Piñol, J., Ogaya, R., \& Filella, I. (1997). Estimation of plant water concentration by the reflectance water index WI (R900/R970). International Journal of Remote Sensing, 18, 2869-2875.

Peterson, D. L., Spanner, D. A., Running, S. W., \& Teuber, K. B. (1987). Relationship of thematic mapper simulator data to leaf area index of temperate coniferous forests. Remote Sensing of Environment, 22, 323-341.

Roberts, D. A., Brown, K., Green, R., Ustin, S., \& Hinckely, T. (1998). Investigating the relationship between liquid water and leaf area in clonal Populus. In R. O. Green (Ed.), Summaries of the Seventh JPL Airborne Earth Science Workshop January 12-16, 1998 (pp. 335-344). Pasadena, California: NASA Jet Propulsion Laboratory.

Roberts, D. A., Ustin, S. L., Ogunjemiyo, S., Greenberg, J., Dobrowski, S. Z., Chen, J., et al. (2004). Spectral and structural measures of northwest forest landscapes at leaf to landscape scales. Ecosystems, 7, 545-562.

Rouse, J. W., Haas, R. H., Schell, J. A., \& Deering, D. W. (1974). Monitoring vegetation systems in the Great Plains with ERTS. In S. C. Freden, E. P. Mercanti, \& M. Becker (Eds.), Third earth resources technology satellite-1 symposium, volume 1: technical presentation, NASA SP-351 (pp. 309-317). Washington, D.C: National Aeronautics and Space Administration.

Running, S. W., Loveland, T. R., Pierce, L. L., Nemani, R. R., \& Hunt, E. R., Jr. (1995). A remote sensing based vegetation classification logic for global land cover analysis. Remote Sensing of Environment, 51, 39-48.
Sims, D. A., \& Gamon, J. A. (2003). Estimation of vegetation water content and photosynthetic tissue area from spectral reflectance: A comparison of indices based on liquid water and chlorophyll absorption features. Remote Sensing of Environment, 84, 526-537.

Stimson, H. C., Breshears, D. D., Ustin, S. L., \& Kefauver, S. C. (2005). Spectral sensing of foliar water conditions in two co-occurring conifer species: Pinus edulis and Juniperus monosperma. Remote Sensing of Environment, 96, 108-118.

Tucker, C. J. (1979). Red and photographic infrared linear combinations for monitoring vegetation. Remote Sensing of Environment, 8, 127-150.

Tucker, C. J. (1980). Remote sensing of leaf water content in the near infrared. Remote Sensing of Environment, 10, 23-32.

Vermote, E. F., Saleous, N. E., Justice, C. O., Kaufman, Y. J., Privette, J. L., Remer, L., et al. (1997). Atmospheric correction of visible to middle-infrared EOS-MODIS data over land surfaces: Background, operational algorithm and validation. Journal of Geophysical Research, 102, 17131-17141.

Vermote, E. F., \& Vermeulen, A. (1999). Atmospheric correction algorithm: Spectral reflectances (MOD09), Algorithm Technical Background.Greenbelt, Maryland: NASA Goddard Space Flight Center (http://modarch.gsfc. nasa.gov/MODIS/ATBD/ atbd_mod09.pdf).

Vivoni, E. R., Gebremichael, M., Watts, C. J., Bindlish, R., \& Jackson, T. J. (2008). Comparison of ground-based and remotely-sensed surface soil moisture estimates over complex terrain during SMEX04. Remote Sensing of Environment, 112, 314-325 (this issue).

Wells, J. M., \& Norman, J. M. (1991). Instrument for indirect measurement of canopy architecture. Agronomy Journal, 83, 818-825.

Woodward, F. I. (1987). Climate \& plant distribution. Cambridge, United Kingdom: Cambridge University Press.

Zarco-Tejada, P. J., Rueda, C. A., \& Ustin, S. L. (2003). Water content estimation in vegetation with MODIS reflectance data and model inversion methods. Remote Sensing of Environment, 85, 109-124.

Zhang, Y., Chen, J. M., \& Miller, J. M. (2005). Determining digital hemispherical photograph exposure for leaf area index estimation. Agricultural and Forest Meteorology, 133, 166-181. 